\title{
Not Your Lucky Day: Romantically and Numerically Special Wedding Date Divorce Risks*
}

\author{
Jan Kabátek ${ }^{\dagger *}$ and David C. Ribar ${ }^{\dagger}$ \\ ${ }^{\dagger}$ Melbourne Institute of Applied Economic and Social Research, \\ The University of Melbourne; ARC Centre of Excellence for Children \\ and Families over the Life Course; and Institute for the Study of Labor (IZA) \\ $\ddagger$ CentER, Tilburg University; and Netspar
}

November 2017

* This research was supported by the Australian Research Council Centre of Excellence for Children and Families over the Life Course. The authors thank Andrew Cherlin, Robert Haveman, Jongsay Yong, colleagues at the Melbourne Institute of Applied Economic and Social Research, workshop participants at the University of North Carolina at Greensboro, and two anonymous reviewers for helpful comments. However, the authors' findings and views are their own and should not be attributed to the Melbourne Institute. For correspondence, email<david.ribar@unimelb.edu.au>. 


\begin{abstract}
Characteristics of couples on or about their wedding day and characteristics of weddings have been shown to predict marital outcomes. Little is known, however, about how the dates of the weddings correlate with marriage durability. Using Dutch marriage and divorce registries from 1999-2013, this study compares the durations of marriages that began on unusually popular wedding dates with marriages on ordinary dates. We identify several distinct types of popular dates, including Valentine's Day and numerically special days (dates with the same or sequential number values, e.g., 9.9.99, 1.2.03), showing that on an adjusted basis, the incidence of weddings on such dates was $137-509 \%$ higher than ordinary dates. The hazard odds of divorce for these special-date weddings were 18-36\% higher than ordinary-date weddings. Sorting on couples' observable characteristics accounts for some of the higher divorce risks, but even after controlling for these characteristics, special-date weddings were more vulnerable, with $10-17 \%$ higher divorce odds compared to ordinary dates. These relationships are even stronger for couples who have not married before.
\end{abstract}

\title{
JEL classification: $\mathrm{J} 1$
}

Keywords: Marriage, divorce, Valentine's Day, commitment, weddings 
In selecting the time for the marriage ceremony precautions of every kind have generally been taken to avoid an unlucky month and day for the knot to be tied (Dyer 1881, 36).

Couples preparing for their wedding day must decide about many things, including the day itself. Many couples pick wedding dates on the basis of convenience for themselves or potential guests, while some others choose dates because they are romantically significant, memorable, or perceived as lucky or auspicious. Press articles across the globe (e.g., Mascarenhas 2010; Ting 2015; Walker 2011) have reported that Valentine's Day and numerically quirky dates, such as December 12, 2012 (12.12.12) are incredibly popular as wedding dates. However, beyond the admonitions in some old proverbs_- "Marry in May, you'll rue the day" (Dyer 1881) - little is known about how the choice of a wedding date might be associated with subsequent marriage outcomes. As we show, some dates may not be as lucky as couples suppose.

Although such linkages might seem far-fetched, there are reasons why wedding date choices might correlate with marital success. Holding a wedding on an unusual date could reduce attendance, while holding one on a popular date could reduce venue availability and increase costs. Low wedding attendance, less formal ceremonies, and high wedding costs have been found to lead to less durable marriages (Francis-Tan and Mialon 2015; Rhoades and Stanley 2014). The choice of a particular wedding date may also be associated with other characteristics of couples, including their attitudes, beliefs, or commitment processes, that affect marriage durability. Our study considers several of these explanations.

We use 1999-2013 marriage registry data from the Netherlands to document that four types of special dates were associated with exceptionally high numbers of weddings:

Valentine's Day and dates with the same, sequential, or mirror numbers for their days, months and years (e.g., 9.9.99, 1.2.03, and 20.08.2008, respectively, using the European 
day.month.year format). We link the marriage records to divorce records and other data to examine how the characteristics of couples and the durations of their marriages differed between those who wed on romantically and numerically special dates and those who wed on other dates. We also examine seasonal and weekly patterns in Dutch marriages and control for the couple's ages, educational attainments, earnings, employment, geographic locations, dissimilarity, and histories of cohabitation, previous marriage and parenting. Previous research has considered several types of numeric preference in family decision making, such as how weddings are more likely to occur when the spouses' years of age or the calendar year end in zero (Ohlsson-Wijk 2014), how births are timed to coincide with or avoid particular dates (Levy, Chung and Slade 2011; Almond, et al. 2015) and how birth timing correlates with child and adult outcomes (Buckles and Hungerman 2013); however, to our knowledge, we are the first to study how special-day marriage timing is associated with later outcomes.

Our article is most closely related to recent studies of wedding characteristics and subsequent marriage outcomes by Rhoades and Stanley (2014) and Francis-Tan and Mialon (2015) but overcomes several limitations of those studies. Rhoades and Stanley only examined 418 respondents, while we examine about 1.1 million, providing us with much more statistical power and the ability to disaggregate results by couple characteristics. Francis-Tan and Mialon analysed a moderately large set of respondents, but they recruited and surveyed people through an internet tool, possibly leading to a non-representative sample. In contrast, our data cover the entire Dutch population who married. Finally, each of the two studies relied on self-reports of wedding characteristics, which might be prone to error. Our information comes from administrative records.

Our analyses produce the first-of-their-kind findings that romantically and numerically special wedding dates are associated with substantially higher divorce risks. 
Documenting this association is a novel contribution. Moreover, we believe that the resultsespecially when considered with other information about couples, including their ages, relationship history, and dissimilarity — have broader implications that provide insights into the determinants of marital stability and possibly of couples' commitment processes.

\section{What's in a date?}

"We came to the realization that 10/10/10 would probably be the best," he said, laughing. "It's definitely an anniversary I can't forget and screw up" (groom quoted by Mascarenhas 2010).

"The easiest day for my poor memory to remember was 9-9-09, and we've been doing everything last-minute ever since ... It was easy, and both of us can remember it and never forget" (bride quoted by Associated Press 2009).

Putting superstition and numerology aside, it is hard to pin a causal explanation on the wedding date itself. We do not see these special dates as causal. Rather, we see the choice of a particular date as a marker for other aspects of the wedding, characteristics of the couple, and even the progression of their relationship.

Romantically and numerically special dates are clearly desirable. Couples in the press clippings consistently described these dates as being memorable. Experimental evidence shows that the use of specially assigned numbers or numbers derived from numerology increases bettors' enjoyment of and sense of control over gambling tasks (Goodman and Irwin 2006), and lottery players often gravitate to visually and arithmetically patterned number combinations (Potter van Loon et al. 2016). The popularity of special dates gives further revealed-preference evidence of their desirability, and Ohlsson-Wijk (2014) has found complementary evidence of digit preferences among Swedish couples who are more likely to marry at ages and in years that end in zero. 
However, this desirability might be a double-edged sword. The popularity of these dates could increase the demand for venues and drive up the costs of the associated weddings. Francis-Tan and Mialon (2015) found that more expensive weddings were associated with less durable marriages. Additionally, Valentine's Day and numerically special dates are not tied to days of the week and could fall on early weekdays when attendance is inconvenient and possibly lower. The popularity of the dates could also reduce the availability of facilities that could accommodate attendees or formal services. Rhoades and Stanley (2014) reported how less attended and less formal weddings were associated with less stable marriages.

While Francis-Tan and Mialon (2015) and Rhoades and Stanley (2014) have given us associational evidence regarding wedding characteristics and marriage outcomes, the reasons for these linkages remain an open question. One potential explanation is the extent of social support for the couple — or the couple's perception of social support. Smaller, less-attended, and informal weddings could indicate that the couple has few social supports or is uncomfortable engaging their social network. However, couples might also choose smaller or less elaborate weddings if they are more certain about their marriage decision and perceive less need for social support (Kalmijn 2004). Religion and traditional attitudes could also be factors, with less religious and less traditional couples being more open to marrying on unusual days. Kalmijn (2004) found that Dutch couples who were less religious or whose characteristics suggested that they were more certain about their marriages had smaller wedding ceremonies. Social support, religion, and traditional attitudes could, in turn, affect subsequent marriage outcomes.

Weddings may also provide insights into relationship processes. Social scientists have theorized about the paths that couples follow to reach the level of commitment involved in a marriage and about the implications that alternative processes have on the durability of the resulting marriages. Family relations researchers have distinguished between internal 
processes, such as relationship- and dedication-driven processes, which occur over time as couples learn about each other, their compatibility, and the quality of a potential union, and external processes, such as event- and constraint-driven processes, which occur as events happen to couples that change their outlook on their relationship or the desirability of marriage (e.g., Ogolsky et al. 2016; Surra and Hughes 1997; Surra et al. 1988; and Stanley et al. 2006). These conceptual approaches generally predict that externally-driven processes will produce more vulnerable marriages, on average, than internally-driven processes. The choice of how and when to wed could be a marker for externally-driven processes.

For example, Rhoades and Stanley (2014) framed their analysis of wedding outcomes within a "sliding versus deciding" model of relationship processess (Stanley et al. 2006). In this conceptualisation, “deciding” couples' commitments grow primarily from increasing dedication and couple satisfaction. These couples decide to marry based on the quality and growth of their relationship — the timing of a wedding would be more likely to follow these internal progressions and less dependent on external concerns. In contrast, "sliding" couples' relationships continue largely because of constraints that accrue that raise the costs of exiting the relationships, especially in the context of cohabitation. Farmer and Horowitz (2015) offer a closely related rational-choice model that emphasises assymetric relationship exit costs. Relationships with these types of constraints or costs are subject to inertia, even if the quality of the match is low in other ways, which may make the couple's marriage behaviour more susceptible at the margin to external cues, like special dates, or leave them ambivalent about the formality or attendance of the ceremony. One other aspect of the relationship inertia is that the sliding (or high exit-cost) couples are likely to cohabit for longer times than other couples. After becoming aware of the quality of their relationship, the deciding couples will either marry or end their relationships. The sliding couples are however unlikely to act until they receive an external cue and this waiting is likely to prolong the time spent in premarital 
cohabitation.

Other theories of commitment processes lead to similar predictions. Attachment theories suggest that people with anxious attachment styles may set lower thresholds for commitment and thus be marginally more susceptible to external considerations, like the opportunity to wed on a special date, than people with secure or avoidant styles (Morgan and Shaver 1999). Couples' attachment styles could, in turn, affect marriage durability.

Rational-choice theorists have advanced investment (Rusbult 1980), exchange (Murstein 1999) and matching and learning (Brien et al. 2006; Rao Sahib and Gu 2002, 2013) models of commitment processes that also have internal components, such as the value of the relationship-specific investment, the anticipation of exchange benefits, or the information about the quality of the match, and external components, such as the net costs of a wedding. These models lead to more nuanced predictions. On the one hand, the chance to marry on a special date could increase the net attractiveness of a wedding and lead to quicker and lowerquality marriage commitments, on average, which might increase the vulnerability of the resulting marriages. On the other hand, if couples have to delay weddings in order to hold them on special days, there would be more time for internal processes like investment or information-gathering to operate, and the resulting marriages might be stronger.

\section{Marriage and divorce in the Netherlands}

To set the context for our empirical analysis and to indicate how wedding and divorce dates are administratively determined in the Netherlands, we first describe Dutch marriage and divorce procedures. Since 1998, the Netherlands has offered two regulated arrangements for couples who want to live together: marriage and registered partnership (it also recognises privately-arranged cohabitation agreements and allows couples to cohabitate informally). The two regulated arrangements offer similar legal benefits and protections; the principal difference is that registered partnerships can be dissolved without a court proceeding if the 
couple is childless. Couples who want to enter either arrangement must first formally register their intention with a municipal authority at least two weeks before the wedding or partnership occurs. The lone exception to this requirement is that registered partners can convert their arrangement into a marriage. The notice requirements and effective waiting periods for marriages are more stringent than those of most other countries and imply that Dutch marriages are less likely to be rushed or result from momentary whims.

The marriage itself requires a civil ceremony, at which point—and more importantly, on which day - the marriage is registered. Religious and secular ceremonies may accompany or follow the civil ceremony, but the civil ceremony and registration almost always indicate the timing of the marriage. There are only a few exceptions. For example, if a wedding occurs off Dutch soil, it is registered when the couple returns to the Netherlands. The wedding date information that we examine comes from the marriage registrations.

Figures from Statistics Netherlands (CBS) indicate that the annual number of different-sex marriages fell from 87,000 in 1998 to 63,000 in 2013 , or from a rate of 5.5 to 3.8 per 1,000 inhabitants. New different-sex partnership registrations rose from fewer than 2,000 in 2001 to about 9,000 in 2013. Because of the modest numbers of new partnership registrations, we only consider formal marriage relationships in our analyses. The decline in marriage rates and rise in cohabitation outside of marriage are similar to trends in the U.S. and other developed countries and are consistent with the "deinstitutionalisation" of marriage (Cherlin 2004). As in the U.S. and Europe, Dutch attitudes on marriage and its alternatives have also become less traditional over time (Treas et al. 2014)

Marriage dissolution in the Netherlands requires a formal legal proceeding. However, as mentioned, registered partnerships that do not involve children can be ended without one. The Netherlands has a unilateral divorce framework in which either partner (or both) can initiate a divorce and the only allowable grounds are irreparable breakdown of the 
relationship. From January 1998 until March 2009, couples could also take advantage of a "flash divorce" procedure under which they could convert their marriages into registered partnerships and then almost immediately dissolve the partnerships. Divorces and partnership dissolutions in the Netherlands take effect once they have been recorded in the municipal population register.

Overall, the personal determinants of divorce in the Netherlands seem similar to those in other countries (see, e.g., the literature review in de Graaf and Kalmijn 2006b). An analysis of Dutch couples' self-reported reasons for divorce motivations by de Graaf and Kalmijn (2006a) found that most cited relationship issues, such as growing apart, inattentive partners, and not being able to talk. Over the period that we study, the number of divorces was relatively constant at around 35,000 per year, or about 10 per 1,000 married couples, although rates were somewhat higher while "flash divorces" were available.

\section{Data}

We construct an analysis dataset from municipal register data collected by CBS over the period 1999 to 2013. The data cover everyone who was at some point registered at one of the Dutch municipalities, and who was therefore (at least temporarily) residing in the Netherlands during the data period. The data include people's marriage histories, including all their wedding dates and if applicable, their divorce dates.

Dates. We focus on four types of special dates: Valentine's Day, same-number dates, sequence dates and mirror dates. The same-number dates share the same number among the day, month and year of the wedding. From 1999-2013 there were 13 such dates, with the first two being 09.09.1999 and 01.01.2001 and the last being 12.12.2012. For the sequence dates, the numbers for the day, month and year of the wedding form an increasing sequence. There were 11 sequence dates, starting with 01.02.2003 and ending with 11.12.2013. The mirror dates have the numerals of the day and month of the wedding arranged in the same format as 
the numerals of the year. The first such date was 20.01.2001, and the last was 20.12.2012, totalling 12 mirror dates. Beyond these four types of dates, we also considered "palindrome" dates (dates that begin with one sequence and end with the same sequence reversed, such as 30.11.03) and reverse sequence dates (dates where the numbers for the day, month and year form a descending sequence, such as 03.02.01) but found that these were not popular.

Some couples might also view holidays as special days. Our analyses account for the public and traditional holidays of New Year's Eve and New Year's Day; Carnival Sunday, Monday and Tuesday; Good Friday; Easter Sunday and Monday; Queen’s Day; Liberation Day; Ascension Day; Whit Sunday and Monday; and Christmas Day and the second day of Christmas. However, we interpret these dates differently than the romantically or numerically special dates because nearly all of the holidays are less popular than a typical day. Many municipal authorities close on several of these days or require special arrangements for weddings. We also include the controls because two of the holidays-New Year's Day in 2001 and Liberation Day in 2005 - occurred on same-number days. In addition, our analysis includes indicators for the days before the Queen's Day, Good Friday and Ascension Day holidays because an initial analysis indicated that they were popular wedding days.

We examine other temporal characteristics of weddings, including general indicators for the years, months, and days of the week on which they occurred. The year indicators help us examine general time trends and account for broad institutional changes, such as the flash divorce policy, and economic changes, including the Global Financial Crisis (GFC). The month indicators allow us to investigate seasonal effects. Days of the week are important not only because some are more convenient or customary than others, but also because Dutch municipal authorities charge different amounts or offer different types of ceremonies on specific days. For example, authorities typically offer a short window on selected weekdays during which couples can marry for free in a simple, civil ceremony and tend to make other 
low-cost ceremonies available on weekdays. The authorities charge premiums, especially for elaborate ceremonies involving the reservation of a room or hall, on Fridays and weekends.

Other controls. Besides providing wedding and divorce dates, the data are informative in other ways. First, they record the dates of people's deaths and indirectly indicate, through the absence of information, whether people are still residing in the country. Thus, we can identify the married couples who are at risk for being observed to divorce and control for censoring in the marriage durations. Second, the data record other characteristics that we can use as controls in our empirical analyses, including each spouse's birth year and month and two-generation immigration background. Third, the data describe people's household compositions, allowing us to measure whether and how long couples were cohabiting prior to their wedding and whether and when they had children. Fourth, the marriage histories tell us whether the wedding is a remarriage for either partner and the number of previous marriages.

In addition, we link the records to other administrative data containing most people's highest attained level of education. ${ }^{1}$ We also link the records to data from tax authorities on earnings and employment for the year of the wedding. We use these data to form measures of each spouse's total gross earnings, months worked, part-time work status, and industry (for the longest held job). We also include dummy variables for the husband's province of residence at the time of the wedding and a 1-5 categorical variable for the degree of urbanisation in the husband's municipality. The geographic variables are included to control for differences in costs, municipal policies, attitudes, and religiosity across areas. Kalmijn and Poortman (2006) and de Graaf and Kalmijn (2006b) found that several of these characteristics predicted Dutch divorces.

\footnotetext{
${ }^{1}$ The administrative records of educational attainment come from municipal authorities. All municipalities provide records for people born on or after 1987, but municipal participation is incomplete for earlier cohorts, with the number of participating areas falling for successively earlier cohorts. The administrative records have been supplemented with national survey data for a small portion of the population. Overall, we observe educational attainment for $58 \%$ of women and $51 \%$ of men. The availability of education information does not appear to be associated with other personal characteristics except for birth cohort and region.
} 
The administrative data do not indicate people's religiousness or social support, but we are able to impute values using information from the Longitudinal Internet Studies for the Social Sciences (LISS) survey panel of approximately 4,500 Dutch households. We measure religiousness from the LISS using married respondents' yes/no agreement to the statement, "Do you consider yourself a member of a certain religion or church community," and we measure social support using married respondents' agreement to the statement, "I know a lot of people that I can fully rely on." Within the LISS, we regress these responses against measures for subjects' ages at marriage and interactions of province indicators and decadal indicators of birth year. The Netherlands has several religiously conservative regions, including a Dutch "Bible Belt" (Sobotka and Adigüzel 2002). We impute religiousness and social support by predicting values based on the observed characteristics in the administrative data. In our multivariate analyses, the predictions of religiosity and social support are identified from the province/birth-cohort interactions.

Our descriptive and multivariate analyses examine the specific characteristics of husbands and wives in the couples (e.g., husband's age and wife's age). However, we also use these characteristics to measure couple dissimilarity by applying the Mahalanobis distance formula - a weighted, generalised quadratic formula that transforms the multidimensional distances into a univariate metric. To construct the measure, we assume

$$
\left(\mathbf{x}_{1 i}-\mathbf{x}_{2 i}\right) \sim \operatorname{dist}(\boldsymbol{\mu}, \mathbf{\Omega}),
$$

where $\mathbf{x}$ represents individual observable characteristics and subscripts 1 and 2 denote husband and wife, respectively. The differences between spousal characteristics are assumed to be drawn from an unspecified distribution with means $\boldsymbol{\mu}$ and variance/covariance $\boldsymbol{\Omega}$. The observable characteristics include age, education level (7-point scale, where the missing education records are replaced by median values), immigration status (dummy indicators for natives, first generation immigrants, and second generation immigrants), and a count measure 
of preceding marriages. The Mahalanobis distance formula is then

$$
M H L_{i}=\sqrt{\left(\left(\mathbf{x}_{1 i}-\mathbf{x}_{2 i}\right)-\overline{\boldsymbol{\mu}}\right)^{\prime} \mathbf{S}^{-1}\left(\left(\mathbf{x}_{1 i}-\mathbf{x}_{2 i}\right)-\overline{\boldsymbol{\mu}}\right)},
$$

where $(\overline{\boldsymbol{\mu}}, \mathbf{S})$ are sample analogues of $(\boldsymbol{\mu}, \boldsymbol{\Omega})$.

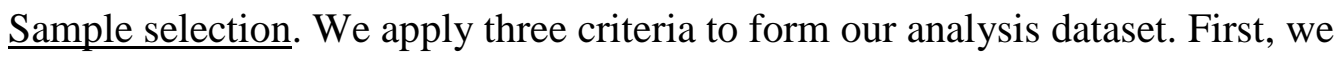
restrict the analysis to weddings that occurred in or after January 1999 because some of the background characteristics are not observable for the prior years, and there were no samenumber or sequential-number dates in the years immediately preceding 1999. This sample restriction also means that our data on marriages and divorce outcomes follow the 1998 enactment of registered partnerships in the Netherlands. We do utilise some earlier data, however, to identify whether the newlyweds were cohabiting prior to their marriage. Second, we only consider marriages between different-sex partners because of the difficulty in classifying husbands and wives in same-sex couples and because of changes in the legal treatment of same-sex marriages in the Netherlands during our analysis period. Third, we drop marriage spells in which either spouse was younger than 18 (the minimum legal marriage age in the Netherlands) or older than 60 years on the wedding day.

\section{Incidence of weddings}

The first step in our empirical analysis is to examine the popularity of the special dates as wedding days. There were 5,479 days during our analysis period and 1,124,707 weddings. The 51 special days during this period comprised 1 percent of the total days, but the 32,374 special-day weddings represented $2.9 \%$ of the total weddings. Put another way, the average number of weddings on a special day was 635 , while the average number on other days was 201. Thus, consistent with press reports from Australia (Ting 2015), the U.S. (Mascarenhas 2010), and the U.K. (Walker 2011), the special dates were unusually popular wedding days in the Netherlands on a relative basis even though they comprised a small 
fraction of weddings overall. The counts of weddings also show the utility of using registry data. Despite their high daily averages, the percentages of weddings that occurred on Valentine's Day, same-number date, sequence date, and mirror date weddings in the data were only $0.4 \%, 1.3 \%, 0.4 \%$, and $0.8 \%$, respectively. Without the large numbers of observations from the registry data, it would be difficult to detect associations.

Figure 1 depicts the average numbers of marriages in our dataset occurring on Valentine's Day (panel 1.a), same-number dates (1.b), sequential-number dates (1.c), mirrornumber dates (1.d), and the 30 days preceding and following these dates. On average, at least twice as many weddings occurred on Valentine's Day as on any of the surrounding dates in the month before and after. At least four times as many weddings occurred on the average same-number date as on most of the surrounding dates. There were also substantially higher numbers of weddings on the mirror dates than on the surrounding dates and modestly higher numbers of weddings on the sequence dates.

Aspects of the graphs, such as the low overall occurrence of weddings surrounding Valentine's Day, reveal that seasonal and other considerations also affect the occurrence of weddings. To account for these, we used OLS to regress the log number of daily marriages on the four types of special dates, year effects, month effects, day-of-week effects, and holidayday effects. Table 1 lists the results in both the standard and exponentiated formats. The exponentiated coefficient estimates indicate that the number of weddings increased $196 \%$ on Valentine's Day, $509 \%$ on same-number dates, $137 \%$ on sequence dates, and $279 \%$ on mirror dates relative to other dates after adjusting for other temporal effects.

The estimates from the OLS models reveal that there were other temporal patterns. The coefficients on the year indicators show that the incidence of weddings generally declined from 1999 through 2013, with the exception of a modest uptick in 2007-2009, just before the GFC. There were also seasonal differences, with the fewest numbers of weddings 
occurring in January and February and the greatest numbers occurring in the months of May through September. Dutch couples either are unaware or pay little heed to the $19^{\text {th }}$ century English admonition against May weddings. Friday was far and away the most popular day of the week to marry. Next in order were Monday and Thursday, possibly owing to the availability of free and low-cost civil ceremonies on those days. The numbers of weddings were much lower on Sundays and on most of the official holidays, which follows from the limited availability of services from municipal authorities on those days. The days which preceded Good Friday, Queen's Day and Ascension Day proved to be very popular, because the wedding guests were not required to go to work on the day after the celebration.

We used a similar procedure to confirm that our choices of special dates covered the most popular wedding dates. In particular, we estimated OLS regressions of the log daily incidence of weddings like those in Table 1 with controls for years, months, days of the week, and holiday days but omitting the controls for the four types of special days. We next examined the residuals from those regressions to find the highest outliers. Out of the 30 dates with the largest positive residuals, 27 were in our categories, and there were no other obvious date clusters among the 50 dates with the largest positive residuals. The median rankings of the residuals for the Valentine's, same number, sequence, and mirror dates were 52, 12, 71, and 29 , respectively.

\section{Couple characteristics}

We next examine how characteristics of the couples differ across alternative wedding days. Table 2 lists average values of characteristics of couples who married on ordinary days in the first column and on each type of special date in the next four columns. The table also indicates whether the averages for each characteristic for the special dates are statistically different from the averages on ordinary dates.

Several types of selection are similar across Valentine's Day and numerically special 
day weddings. People who married on special dates were older, more likely to have been born in the Netherlands, more likely to be remarrying, more likely to have children already living in the household, less educated, and less likely to be religious or have social support than people who married on ordinary dates.

Average values for the Mahalanobis distance measures further indicate that spouses who married on each of the special days except mirror days were less matched on their observable characteristics than spouses who married on ordinary days. High degrees of dissimilarity increase the risk of dissolution, so the differences by type of marriage date indicate that special dates are associated with more vulnerable matches.

Other types of selection differed across types of days in ways that suggested that the couples who wed on Valentine's Day were less advantaged than average, while couples who married on numerically special days were more advantaged. Employment was lower among couples who married on Valentine's Day but higher among couples who married on numerically special days. Husbands' earnings were also lower among the Valentine's Day couples but higher among the other special-day couples.

Couples who married on Valentine's Day were more likely to have a child within nine months of the wedding (more likely to be expecting a child when they married) than couples who married on ordinary dates. However, this appears to be a seasonal association, as the proportions of "expecting" couples among those who wed on Valentine's Day and in February generally were each just over one fifth. In contrast, couples who married on numerically special dates were less likely to have a child within nine months of the wedding date than couples who married on ordinary dates. Couples who married on numerically special days were more likely to cohabitate than couples who married on ordinary dates or on Valentine's Day. Couples who married on Valentine's Day were more likely to have cohabited for less than one year and less likely to have cohabited for more than two years 
than couples who married on ordinary days.

\section{Marriage durations}

We used the data to create marriage spell records whose durations either ended with divorce (complete spells) or with right-censoring when a partner died, the couple left the country, or the spell reached the end of our observation window on 31 December 2013 (partial spells).

Marriages that began on most of the special dates were less durable than marriages on other dates. Figure 2 shows smoothed non-parametric hazard estimates of the failure rates of special- and ordinary-date marriages from 1999-2013 for durations up to 11 years, and Table 3 lists the cumulative failure rates, along with $95 \%$ confidence intervals, at selected durations. The hazard and cumulative failure estimates adjust for the loss of information in the partial spells of marriage durations. The hazard estimates are useful for understanding the duration dependence patterns (how failure risks vary over the course of marriages), while the cumulative failure estimates give a better sense of the magnitudes of the differences.

Estimates from these procedures indicate that marriages that began on Valentine's Day and same-number dates were more likely to fail by substantively and statistically significant amounts at nearly all durations. By their third anniversaries, $6 \%$ of Valentine's Day marriages, $5 \%$ of same-number-date marriages, and $4 \%$ of ordinary-date marriages were predicted to have failed. Calculated another way, the third-anniversary failure rates of Valentine's Day and same-number date marriages were $45 \%$ and $30 \%$ higher, respectively, than the failure rate of ordinary-date marriages. By their fifth anniversaries, $11 \%$ of Valentine's Day marriages, $10 \%$ of same-number-date marriages, and $8 \%$ of ordinary-date marriages were predicted to fail (excess failure odds of $41 \%$ for the Valentine's Day marriages and $28 \%$ for the same-number marriages), and by their ninth anniversaries, $21 \%$ of Valentine's Day marriages, $19 \%$ of same-number-date marriages, and 16\% of ordinary-date 
marriages were predicted to fail (excess failure odds of $36 \%$ for the Valentine's Day marriages and $23 \%$ for the same-day marriages).

Marriages that began on sequential-number dates were more likely to fail at longer durations than marriages that began on ordinary dates, and marriages that began on mirror dates were little different from ordinary-date marriages.

The different durations of special- and ordinary-date marriages could partly reflect differences in other characteristics that are mutually associated with marital stability and the choice of a wedding date. The differences in observed characteristics prompted us to estimate multivariate Cox proportional-hazard (PH) models of the hazard probabilities of marital dissolution. The Cox PH model is specified as

$$
\lambda_{t}(t \mid \mathbf{x}, \boldsymbol{\beta})=\lambda_{0}(t) \exp \left(\mathbf{x}^{\prime} \boldsymbol{\beta}\right)
$$

where $t$ denotes the marriage duration and $\lambda_{0}(t)$ is a non-parametric estimator of the baseline hazard, which is a function of duration $t$ alone. We report exponentiated coefficients from three specifications of the model in Table 4.

The first column lists estimates from a specification that only includes binary indicators for the four types of special days (the relevant comparison is an ordinary day). The estimates indicate that the log odds ratio of the hazard of divorce was $37 \%$ higher if the couple married on Valentine's Day, 26\% higher if they married on a same-number date, $18 \%$ higher if they married on a sequential-number date, but only slightly and not significantly higher if they married on a mirror date.

The second column reports estimates from a specification that accounts for other temporal patterns by including dummy controls for each year, month, day of the week, Dutch public and traditional holiday, and the popular days preceding holidays. When we control for these temporal characteristics, the positive association between a Valentine's wedding and divorce attenuates by about a third while the associations of marriages on the other special 
dates with divorce strengthen slightly. The change in the coefficient for Valentine's Day occurs mainly because of the inclusion of month controls, which reveal that marriages that start in February are more vulnerable than marriages that start in several other months.

Among the other temporal variables, the year indicators show that the risks of divorce generally decreased until 2006 and then plateaued. The month indicators show that divorce risks were highest for weddings that occurred in January and generally high for those that occurred in winter and summer but low for those that occurred in the spring and early fall. Marriages were more vulnerable if couples wed on a Monday or Tuesday but more durable if they married on the weekend. Marriages were also at higher risk of divorce if the weddings occurred on Carnival Monday or New Year's Eve but at decreased risk if the weddings were held on Easter Monday, Christmas Day, or the days before Queen's Day or Ascension Day. The third specification adds controls for characteristics of both spouses, including dummies for their calendar ages, immigration backgrounds, numbers of preceding marriages, educational attainment, employment, industry, pregnancy at the time of marriage, presence of premarital children in the household, province, degree of urbanisation, imputed religiousness and social support, and piecewise linear splines formed from the log annual earnings and Mahalanobis distance measures with knots at the 25th, 50th and 75th quantiles of their distributions. Instead of reporting the 84 coefficients for the dummy indicators of the husband's and wife's ages, we plot the point estimates and $95 \%$ confidence intervals in Figure 3. The table also only reports coefficients for the second, third and fourth most frequent industrial sectors for husbands and wives with the largest sectors used as the baseline (complete results are available on request). ${ }^{2}$ When we control for personal characteristics, the associations for most of the special days remain significant but attenuate

\footnotetext{
${ }^{2}$ Metals and engineering, which employed $7.3 \%$ of the grooms is the reference category for them; health care, which employed $19.9 \%$ of the brides, is the reference category for them.
} 
with the log odds ratio of the hazard of divorce being $11 \%$ higher if the couple married on Valentine's Day, $17 \%$ higher if they married on a same-number date, $10 \%$ higher if they married on a sequential-number date, and slightly but not significantly higher if they married on a mirror date.

The controls for couple characteristics also attenuate most of the other temporal associations, though the general patterns for the annual trends, seasons, and days of the week remain. The associations for holiday days also become weaker, with the associations for Carnival Monday, Maundy Thursday, Easter Monday, and Christmas losing their significance but with the associations for New Year's Eve and the days preceding Queen's Day and Ascension Day remaining significant and with the association for New Year's Day becoming significantly positive.

Divorce risks generally fell with the couple's ages at the time of marriage, especially with the wife's age. Divorce risks were also lower if the spouses held higher degrees, had high earnings, worked for only a portion of the year, lived in a less urban area, if the wife was a first generation immigrant, or if the couple was imputed to be religious or have strong social support. Divorce risks rose if either of the spouses was remarrying and rose even more if either was entering a third or higher-order marriage. There were differences across industries, with men working in business services, lending companies, and health care having higher risks than the baseline category of metals and engineering and with women in retail and lending companies having higher risks than the baseline category of health care. ${ }^{3}$ There were also geographic differences. ${ }^{4}$

Couples who cohabited prior to their wedding - the vast majority of marrying couples in the Netherlands - were more prone to divorce than couples who did not cohabit. However,

\footnotetext{
${ }^{3}$ The baseline categories for men and women are chosen to be the employment sectors with the largest share of workforce of the respective gender.

${ }^{4}$ Limburg is the omitted province in Table 4.
} 
the risks of divorce decreased with the length of cohabitation. The results for couples' cohabitation status may seem counter-intuitive, especially from the theoretical perspectives of rational investment or learning (e.g., Rao Sahib and Gu 2002, 2013); however, this is a common empirical finding (see, e.g., Brien et al. 2006 and Farmer and Horowitz 2015 and see Amato 2010 for a review of other studies). The hazard for divorce also increased if there was a child in the household at the time of the wedding but decreased if a child was born in the first nine months of the marriage.

We examined differences in each couple's characteristics through a piecewise linear spline on our dissimilarity index, which allowed the index's association with divorce to vary with the amount of dissimilarity. Dissimilarity of spouses made marriages more vulnerable, and the model estimates show that divorce risks rose across the entire range of dissimilarity.

\section{Sensitivity analyses}

Alternative specifications. The third specification in Table 4 includes many domains of personal and couple controls, and as discussed, the inclusion of these controls attenuates the coefficients on the special days. As a set of sensitivity tests, we systematically dropped domains of controls to see which ones did and did not affect the estimated associations for the special days. The first six rows of Table 5 list coefficient estimates for the special day indicators from these specifications. The estimates indicate that the special day results are sensitive to the omission of controls for couples' ages; educational attainments; cohabitation, marriage, and childbearing histories; and dissimilarity. Interestingly, however, the special day coefficients were not sensitive to the omission of controls for geography nor for earnings and employment. The robustness of the estimates to the omission of geographic controls suggests that our findings are not artefacts of spurious correlations with religion or attitudes.

Another possible concern with our multivariate analyses is the number of observations with missing data on either the husband's or wife's educational attainment. The 
seventh row of Table 5 reports results from a specification that drops these observations. Estimates of the association of special days with divorce risks from these specifications are slightly higher than those reported in Table 4.

The eighth row in Table 5 reports results from a specification that is estimated over all our years of available data, 1995-2013. We omitted 1995-1998 because there were no samenumber or sequential-date days in this period, and because we did not have employment and geography data for those years. As a result, the eighth specification lacks the employment and geography covariates, and should be compared to the specification in the ninth row, which also omits these controls and is estimated on the original 1999-2013 sample. As the estimates indicate, including the four extra years of data makes almost no difference in our findings.

The imputed values for religiousness and social support are identified through interactions of province indicators and decadal birth cohort indicators. As a more general approach for controlling for religiousness and social support but also to account for other characteristics, such as attitudes, that might be associated with geography and birth cohort, we re-estimated our models with all of the province/cohort interactions, instead of the imputed measures. Row 10 of Table 5 reports the results and shows that our findings are fully robust to these controls.

At the suggestion of a reviewer, we also estimated models with more elaborate temporal controls that included interactions of the days of the week with the months of the year. These models were intended to capture days during the spring, summer, and fall, especially Fridays, that might be particularly popular and associated with both high cost and high attendance. We did not detect a strong seasonal pattern for Fridays in our divorce models, and our estimates for Valentine's Day and same-number dates (shown in Row 11) are robust to these controls, though our estimates for sequential-number dates become smaller and insignificant. 
Subgroup analyses. Previous research (e.g., de Graaf and Kalmijn 2006b and Kalmijn and Poortman 2006) and our estimates have shown that divorce risks are higher if either spouse was remarrying or if the couple cohabited prior to marriage. Our descriptive analyses also indicate that couples' marriage and cohabitation histories were associated with the choice to marry on a special day. We re-estimated the Cox PH marriage duration models with the full sets of temporal and personal controls separately for these different types of couples. Rows 12-15 of Table 5 report results from four specifications: a model restricted to couples in which both partners were marrying for the first time, a model for couples in which one or both of the partners were remarrying, a model for couples who cohabited for less than one month prior to marrying, and a model for couples who cohabited longer prior to marrying.

The estimates indicate that weddings on romantically and numerically special dates were particularly strongly associated with divorce risks for first-marriage couples, with Valentine's Day, same-number dates and mirror-number dates having statistically significant coefficients. Same-number date weddings were associated with higher divorce rates for all of the groups, while Valentine's Day weddings were associated with higher divorce odds for all groups except those who were remarrying. Divorce odds were also higher for those marrying on sequence dates, but the associations were not statistically significant for couples in which one or the other of the partners was remarrying or couples who had not cohabited.

Finally, we considered alternative sets of special days. There were a handful of other special days_-January 1, 2000 (Y2K day); leap year days in 2000, 2004, 2008, and 2012; and nearly same-number days, such as November 1, 2011 (1.11.11) and February 2, 2000 $(2.2 .2 \mathrm{~K})$ — that were unusually popular dates for weddings in the Netherlands. Y2K day and the leap year days did not fit with our other special day categories and lacked enough weddings to analyse with precision. Our results are similar when we drop these dates from our set of ordinary dates. For the nearly same-number dates, we have estimated alternative 
specifications that include these with the exact same-number dates and obtained similar results to those we have reported.

We also considered dates with the same numbers for their days and months but not their years, such as March 3, 2007. A modification of the OLS analysis from Table 1 to include these dates shows that they were modestly popular - the incidence of weddings was $26 \%$ higher on these dates relative to other ordinary dates on an adjusted basis. These dates were associated with divorce risks that were 3\% higher than ordinary dates and statistically significant, which provides additional support for our other special-day findings. Accounting for these partial same-number dates did not alter our other findings.

\section{Discussion}

Our descriptive and multivariate analyses of Dutch registry data show that Valentine's Day, same-number dates, sequence-number, and mirror-number dates are exceptionally popular wedding dates. The results are consistent with press reports of the surges in the numbers of weddings on these dates in other countries. Our analyses show other expected patterns in the timing of Dutch weddings, with the numbers of weddings being higher in warmer months than colder months and with the numbers being lower on public holidays. One pattern that is different from other countries, including the U.S. and Australia, is that Friday is the most popular day of the week for Dutch couples to marry followed by Monday.

The novel finding of our study is that Valentine's Day, same-number dates, and sequence number dates were not only popular but also associated with statistically and substantively higher risks of divorce. These differences appear in analyses with and without controls for other covariates. In event-history analyses that only account for the baseline duration patterns, the log odds ratio of divorce was 37\% higher for Valentine's Day weddings, $26 \%$ higher for same-number date weddings, and $18 \%$ higher for sequence date weddings than for ordinary date weddings. Some of these differences are attributable to other 
vulnerabilities of the couples. In particular, couples who wed on special dates tended to have less education, were more likely to have children already living in their households, were more likely to have one or both partners remarrying, and were less similarly matched than couples who wed on ordinary dates. However, even when we control for these characteristics the log odds ratio of divorce was still 11\% higher for Valentine's Day weddings, $17 \%$ higher for same-number date weddings, and $10 \%$ higher for sequence date weddings than for ordinary weddings. Divorce risks were also slightly higher for mirror-number date weddings than for ordinary date weddings but the differences were not statistically significant.

Our analyses also reveal that other elements of marriage timing correlated with divorce risks. Weddings that occurred in the winter and the middle of summer had higher divorce risks, but those that occurred in the spring and early fall had lower risks. Weddings that occurred on Mondays and Tuesdays also had high divorce risks, while marriages that occurred on Fridays or weekend days had lower risks.

Marrying on a romantically or numerically unique day appears to be an indicator for marriage vulnerability rather than causal in and of itself. Although we cannot observe the underlying mechanism, the patterns in the data suggest that some explanations are more likely than others. The associations for special days in our multivariate specifications do not appear to be artefacts of spurious correlations with religious beliefs or attitudes. Our administrative data do not allow us to test this directly; however, we were able to impute controls for religiousness based on geographic and birth cohort information. As expected, religiousness is negatively associated with divorce, but the added controls (and general controls for interactions of geography and birth cohorts) do not change our special-date results.

As we discussed, special wedding dates may be associated both with lower attendance due to inconvenient timing and limited space at facilities, and with higher expenses due to the 
popularity of weddings on these dates. Attendance (Rhoades and Stanley 2014) and cost (Francis-Tan and Mialon 2015) have each been found to be associated with marriage outcomes. However, other temporal patterns in our analysis suggest that attendance is a more relevant characteristic for Dutch couples' marriage durability than cost. In particular, we observe elevated risks of divorce from Monday and Tuesday weddings when both costs and attendance tend to be low, and lower risks for weddings on the days before the Queen's Day and Ascension Day holidays and on summer Fridays when attendance and costs should be high. Again, it is important to stress that the role of wedding attendance is associational. Rather than directly contributing to the divorce risks, attendance may indicate the degree of social support for the couple. We find evidence, based on imputed measures, that social support is negatively associated with divorce. However, we also find that the controls for social support do not change the special-day estimates.

Several alternative theories of relationship processes indicate that externallyinfluenced commitment processes may produce more vulnerable and less durable marriages than internally-driven processes. Consistent with these predictions, we find that Dutch couples who marry on special days are more vulnerable along several dimensions, including their education levels, their marriage and childbearing histories, and their within-couple dissimilarity. However, within this class of theories, we see some discrepancies with the predictions of the rational-choice models of commitment. Although these models also have internal and external components, the external components in most of them weaken marriages by speeding up the commitment process. As mentioned, the Dutch intentionregistration requirement puts some brakes on couples who might be in rush to marry. Further, we find that couples who wed on special days were older and, at least for the numerically special days, more likely to have cohabited for long periods of time. These results suggest that couples delayed their wedding dates — rather than hastened them — to accommodate 
special days, which should have led to more durable marriages under the rational-choice models. Our finding that cohabitation increased divorce risks is also inconsistent with standard rational-choice models but fits with the sliding versus deciding and asymmetric cost approaches. The accumulation of barriers to exiting a relationship is hypothesized to contribute to sliding behavior, and our finding that special day couples are more likely to have children prior to marriage is consistent with these types of barriers.

Further research is needed to test the religious, wedding-cost and rational-choice explanations more definitively and to distinguish between the many remaining explanations, including those involving wedding attendance, social support, and sliding versus deciding behaviour. The popularity of romantically and numerically special wedding dates extends beyond the Netherlands, and more research is needed to establish whether the deleterious associations appear in other countries.

The decision to marry involves choices about whether and when to marry. For some couples, considerations of when to marry, specifically the opportunity to hold a wedding on a romantically or numerically special date, may influence the decision of whether to marry and result in more vulnerable marriages. And more generally, characteristics of the wedding may indicate some couples' chances of marriage success. 
Funding: Both authors were supported by the Australian Research Council Centre of Excellence for Children and Families over the Life Course.

Conflicts of Interest: The authors declare that they have no conflicts of interest.

\section{References}

Almond, Douglas, Christine Pal Chee, Maria Micaela Sviatschi, and Zhong Nan. 2015. "Auspicious birth dates among Chinese in California." Economics and Human Biology 18: 153-9.

Amato, Paul R. 2010. "Research on Divorce: Continuing Trends and New Developments." Journal of Marriage and Family 72 (3): 650-66.

Associated Press. 2009. "Nine Times the Bliss: 9/9/09 Big Lucky Day for Weddings." nydailynews.com. September 9. Accessed May 29, 2016. http://www.nydailynews.com/news/national/times-bliss-9-9-09-big-lucky-day-lasvegas-weddings-article-1.164851.

Brien, Michael J., Lee A. Lillard, and Steven Stern. 2006. "Cohabitation, marriage, and divorce in a model of match quality." International Economic Review 47 (2): 451-94.

Buckles, Kasey, and Daniel Hungerman. 2013. "Season of Birth and Later Outcomes: Old Questions, New Answers." Review of Economics and Statistics 95 (3): 711-24.

Cherlin, Andrew. 2004. "The Deinstituionalization of American Marriage." Journal of Marriage and Family 66 (4): 848-61.

de Graf, Paul M., and Matthijs Kalmijn. 2006a. "Divorce Motives in a Period of Rising Divorce." Journal of Family Issues 27 (4): 483-505.

de Graf, Paul M., and Matthijs Kalmijn. 2006b. "Change and Stability in the Social Determinants of Divorce: A Comparison of Marriage Cohorts in the Netherlands." European Sociological Review 22 (5): 561-72.

Dyer, T. F. Thiselton. 1881. Domestic Folk-lore. London: Cassell, Petter, Galpin.

Farmer, Amy, and Andrew Horowitz. 2015. "Strategic Non-marital Cohabitation: Theory and Empirical Implications." Journal of Population Economics 28 (1): 219-37.

Francis-Tan, Andrew, and Hugo M. Mialon. 2015. "'A Diamond is Forever' and Other Fairy Tales: The Relationship between Wedding Expenses and Marriage Duration." Economic Inquiry 53 (4): 1919-30.

Goodman, Joseph, and Julie Irwin. 2006. "Special Random Numbers: Beyond the Illusion of Control." Organzational Behavior and Human Decision Processes 99 (2): 161-74.

Kalmijn, Matthijs. 2004. "Marriage Rituals as Reinforcers of Role Transitions: An Analysis of Weddings in The Netherlands." Journal of Marriage and Family 66 (3): 582-94.

Kalmijn, Matthijs, and Poortman Anne-Rigt. 2006. "His or Her Divorce? The Gendered Nature of Divorce and Its Determinants." European Sociological Review 22 (2): 20114.

Levy, Beka, Pil H. Chung, and Martin D. Slade. 2011. "Influence of Valentine's Day and Halloween on Birth Timing." Social Science \& Medicine 73: 1246-48.

Mascarenhas, Rohan. 2010. "Thousands of Marrying Couples Make 10/10/10 A Date to Remember." nj.com. October 10. Accessed May 29, 2016.

http://www.nj.com/news/index.ssf/2010/10/thousands_of_weddings_make_101.html.

Morgan, Hillary J., and Phillip R. Shaver. 1999. "Attachment processes and commmitment to romantic relationships." In Handbook of Interpersonal Commitment and Relationship Stability, edited by Jeffrey M. Adams and Warren H. Jones, 109-24. New York: Springer Science+Business Media, LLC. 
Murstein, Bernard. 1999. "The relationship of exchange and commitment." In Handbook of Interpersonal Commitment and Relationship Stability, edited by Jeffrey M. Adams and Warren H. Jones, 205-20. New York: Springer Science+Business Media, LLC.

Ogolsky, Brian, Catherine Surra, and Monk J. Kale. 2016. "Pathways to Commitment to Wed: The Development and Dissolution of Romantic Relationships." Journal of Marriage and Family 78 (2): 293-310.

Ohlsson-Wijk, Sofi. 2014. "Digit Preferences in Marriage Formation in Sweden: Millennium Marriages and Birthday Peaks." Demographic Research 30 (Article 25): 739-52.

Potter van Loon, Rogier, Martijn ven den Assem, Dennie van Dolder, and Tong Wang. 2016. "Number Preferences in Lotteries." Judgment and Decision Making 11 (3): 243-59.

Rao Sahib, Padma, and Xinhua Gu. 2002. "'Living in Sin' and Marriage: A Matching Model." Journal of Population Economics 15 (2): 261-82.

Rao Sahib, Padma, and Xinhua Gu. 2013. "As good as married? A model of premarital cohabitation and learning." Journal of Mathematical Sociology 37: 133-58.

Rhoades, Galena K., and Scott M. Stanley. 2014. Before 'I Do': What Do Premarital Experiences Have to Do with Marital Quality Among Today's Young Adults? University of Virginia, Charlottesville: The National Marriage Project. Accessed May 15, 2016. http://before-i-do.org/.

Rusbult, Caryl. 1980. "Commitment and satisfaction in romantic associations: a test of the investment model." Journal of Experimental Social Psychology 16: 178-86.

Sobotka, Tomás, and Feray Adigüzel. 2002. Religiosity and Spatial Demographic Differences in the Netherlands. Groningen: University of Groningen.

Stanley, Scott M, Galena Kline Rhoades, and Howard J. Markman. 2006. "Sliding versus deciding: inertia and the premarital cohabitation effect." Family Relations 55 (4): 499509.

Surra, Catherine A., and Deborah K. Hughes. 1997. "Commitment processes in accounts of the development of premarital relationships." Journal of Marriage and Family 59 (1): 5-21.

Surra, Catherine A., Peggy Arizzi, and Linda A. Asmussen. 1988. "The association between reasons for commitment and the development and outcome of marital relationships." Journal of Social and Personal Relationships 5 (1): 47-63.

Ting, Inga. 2015. "The Science behind the Weird Pattern in Australia's Most Popular Wedding Dates." Sydney Sun Herald, December 6, First ed.: 7. http://www.smh.com.au/national/what-are-the-most-popular-wedding-dates-inaustralia-20151204-glfrod.

Treas, Judith, Jonathan Lui, and Zoya Gubernskaya. 2014. "Attitudes on Marriage and New Relationships: Cross-National Evidence on the Deinstitutionalization of Marriage." Demographic Research 30 (Article 54): 1495-1526.

Walker, Peter. 2011. "Global Wedding Rush Marks 11-11-11." theguardian.com. November 11. Accessed May 29, 2016. http://www.theguardian.com/news/blog/2011/nov/11/1111-11-11-11-date-events. 
Figure 1. Average daily number of weddings in the 60-day interval around the special dates

a)

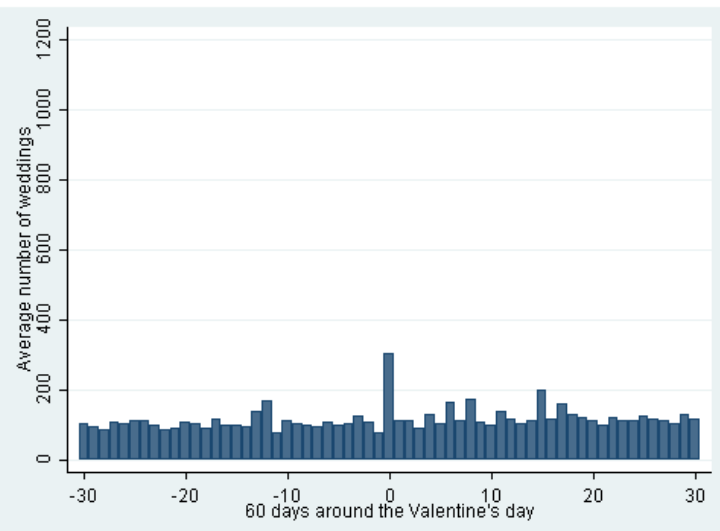

b)

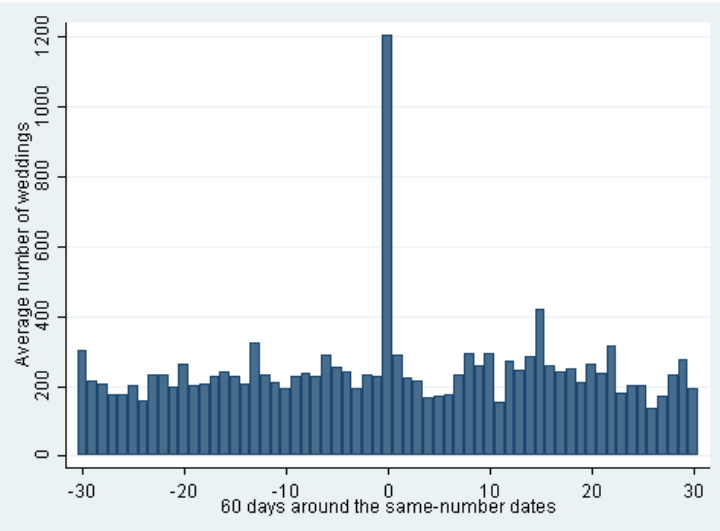

c)

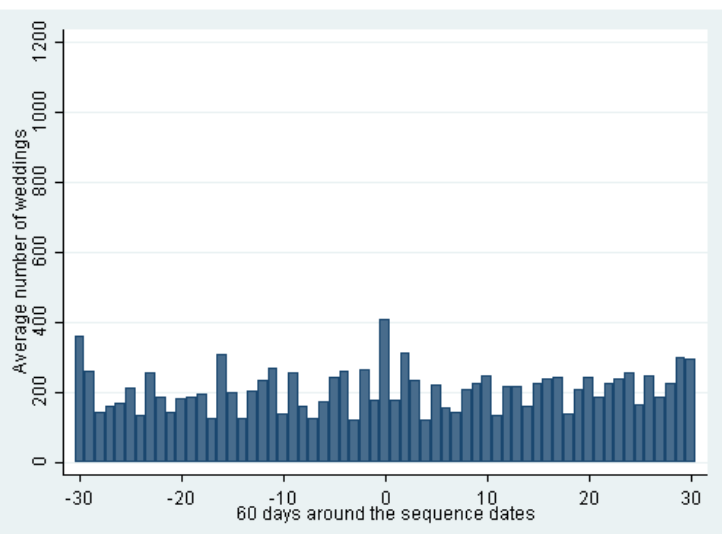

d)

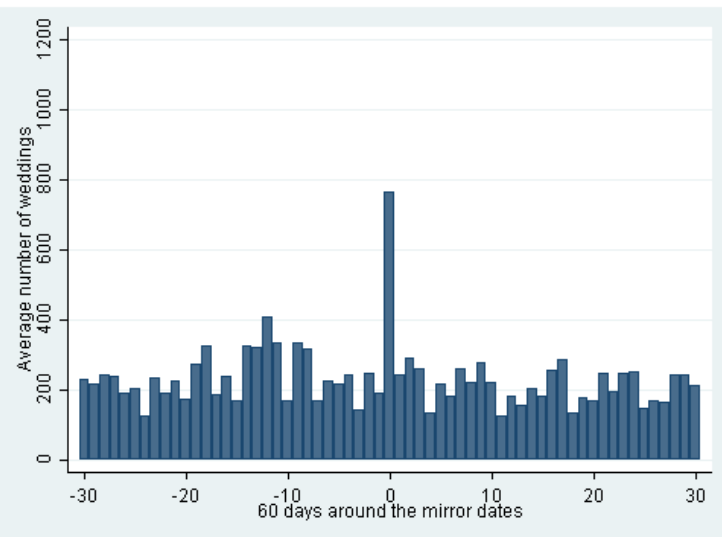

Note: Authors' estimates of the average number of daily weddings in the Netherlands, using information from 1999-2013. 
Figure 2. Smoothed non-parametric hazard rates of divorce for marriages started on the four types of special dates and marriages started on ordinary dates

a)

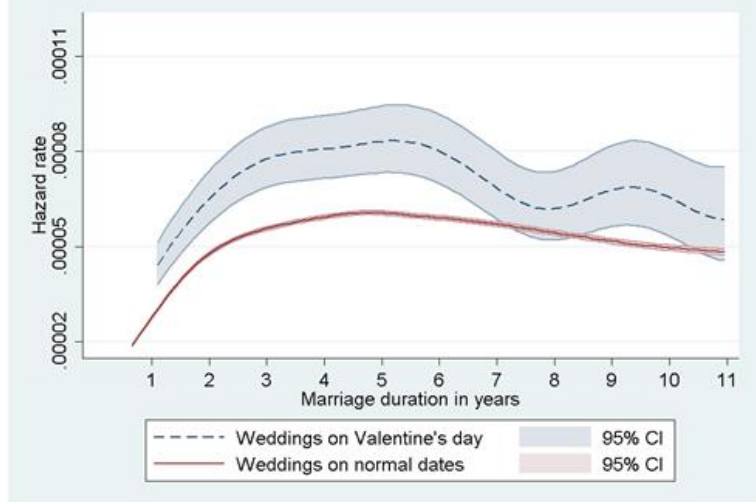

c)

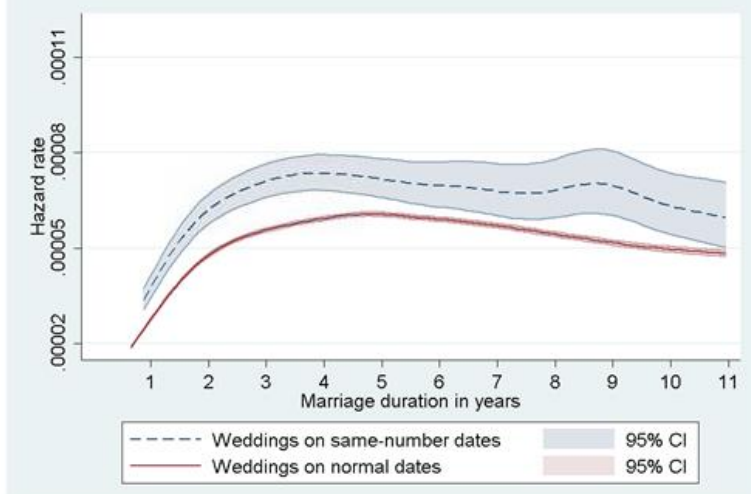

b)

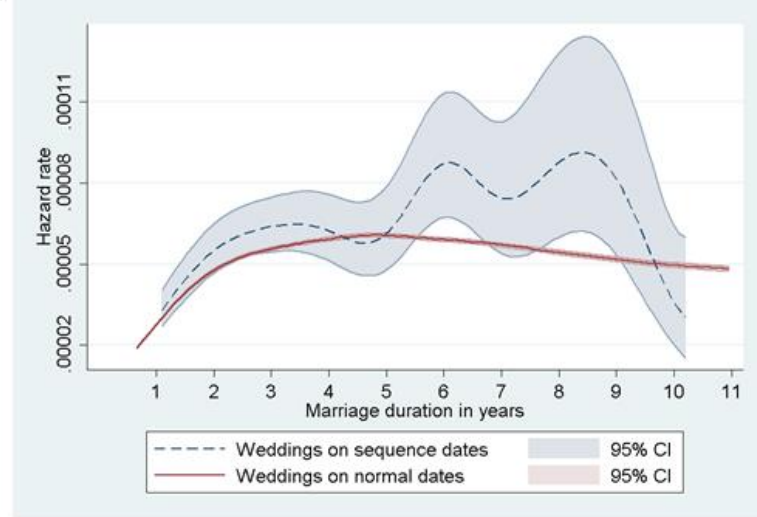

d)

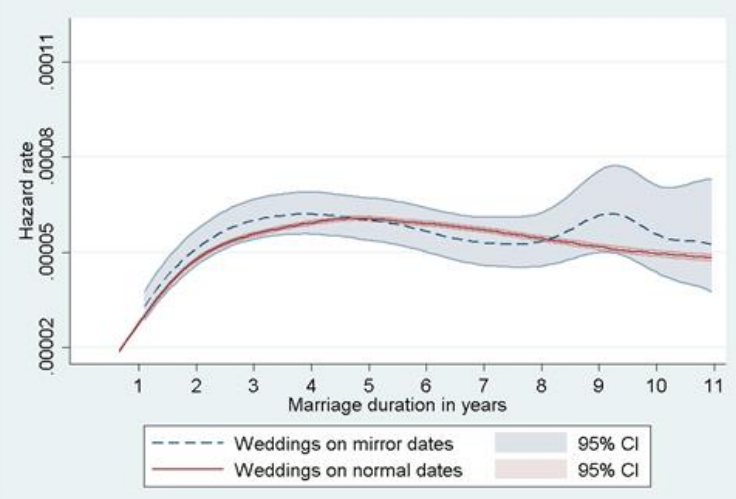

Note: Authors' estimates of hazard rates using linked marriage, divorce, and other registry data for marriages of different-sex couples ages 18-60 in the Netherlands from 1999-2013. 95\% confidence intervals indicated by shaded regions. 
Figure 3. Exponentiated coefficients for the husbands' and wives' age dummies from the full (third) specification of the Cox PH model of divorce risk in Table 4

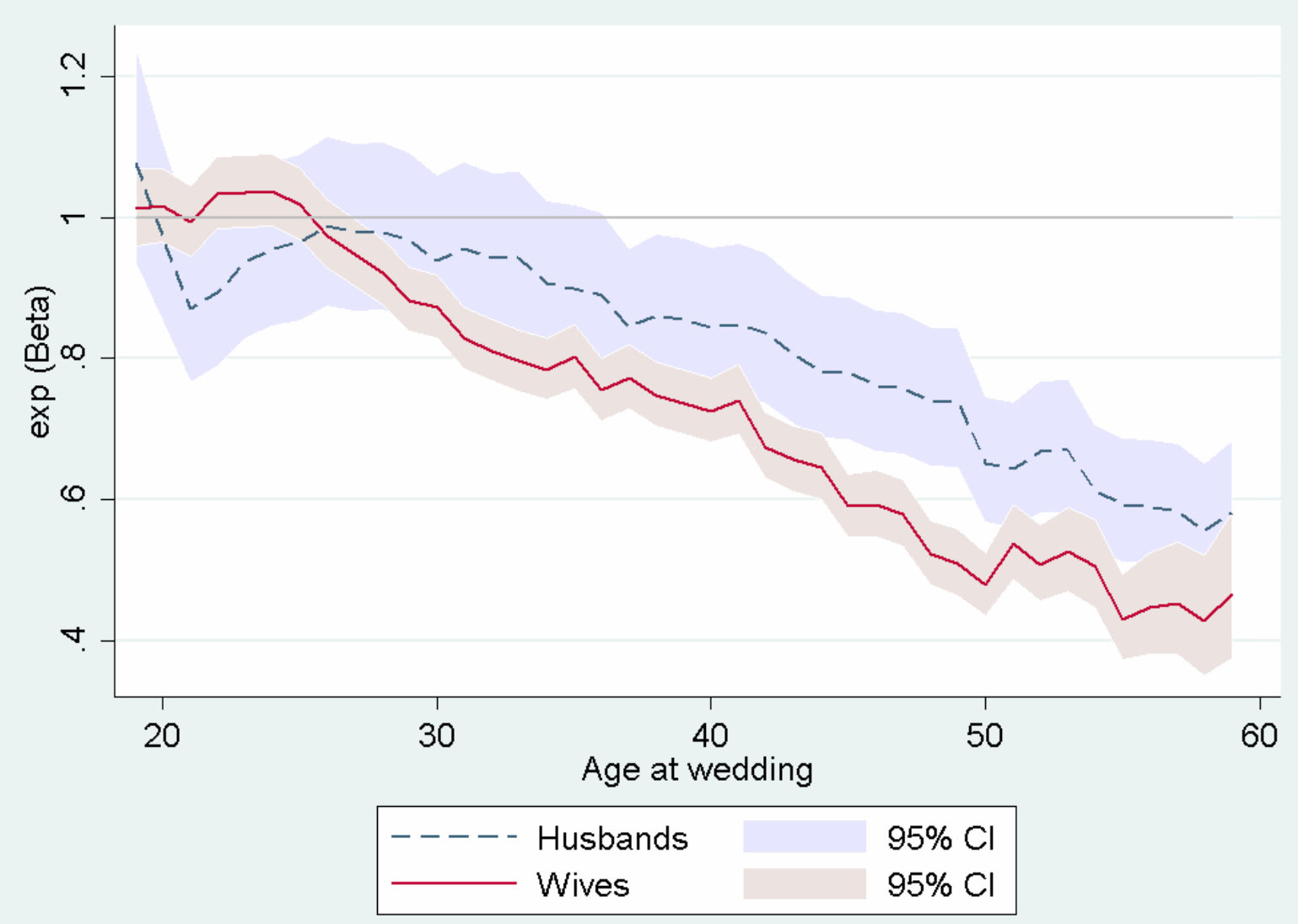

Note: Authors' estimates of exponentiated coefficients of dummy indicators of husbands' and wives' ages from the Cox PH model of marriage durations from the third column of Table 4 that used linked marriage, divorce, and other registry data for 1,124,707 marriages of different-sex couples ages 18-60 in the Netherlands from 1999-2013. 95\% confidence intervals indicated by shaded regions. 
Table 1: Coefficients from OLS model of log daily number of marriages

\begin{tabular}{|c|c|c|c|c|}
\hline Variable & Coefficient & s.e. & $\exp ($ coefficient $)$ & s.e. \\
\hline \multicolumn{5}{|l|}{ Special dates } \\
\hline Valentine's Day & $1.086 * * *$ & 0.099 & $2.963 * * *$ & 0.292 \\
\hline Same number dates & $1.806 * * *$ & 0.104 & $6.086 * * *$ & 0.633 \\
\hline Sequence dates & $0.861 * * *$ & 0.113 & $2.365 * * *$ & 0.266 \\
\hline Mirror dates & $1.332 * * *$ & 0.108 & $3.790 * * *$ & 0.408 \\
\hline \multicolumn{5}{|l|}{ Year of wedding } \\
\hline 2000 & 0.034 & 0.028 & 1.035 & 0.029 \\
\hline 2001 & $-0.056^{* *}$ & 0.028 & $0.946 * *$ & 0.026 \\
\hline 2002 & -0.040 & 0.028 & 0.960 & 0.027 \\
\hline 2003 & $-0.097 * * *$ & 0.028 & $0.907 * * *$ & 0.025 \\
\hline 2004 & $-0.163 * * *$ & 0.028 & $0.849 * * *$ & 0.023 \\
\hline 2005 & $-0.200 * * *$ & 0.028 & $0.818 * * *$ & 0.023 \\
\hline 2006 & $-0.215^{* * *}$ & 0.028 & $0.806 * * *$ & 0.022 \\
\hline 2007 & $-0.211 * * *$ & 0.028 & $0.810 * * *$ & 0.022 \\
\hline 2008 & $-0.183 * * *$ & 0.028 & $0.833 * * *$ & 0.023 \\
\hline 2009 & $-0.216^{* * *}$ & 0.028 & $0.805 * * *$ & 0.022 \\
\hline 2010 & $-0.248 * * *$ & 0.028 & $0.780 * * *$ & 0.022 \\
\hline 2011 & $-0.366^{* * *}$ & 0.028 & $0.694 * * *$ & 0.019 \\
\hline 2012 & $-0.412 * * *$ & 0.028 & $0.662 * * *$ & 0.018 \\
\hline 2013 & $-0.678 * * *$ & 0.028 & $0.508 * * *$ & 0.014 \\
\hline \multicolumn{5}{|l|}{ Month of wedding } \\
\hline February & $0.095 * * *$ & 0.026 & $1.100 * * *$ & 0.029 \\
\hline March & $0.191 * * *$ & 0.025 & $1.211 * * *$ & 0.030 \\
\hline April & $0.539 * * *$ & 0.026 & $1.714 * * *$ & 0.044 \\
\hline May & $0.933 * * *$ & 0.025 & $2.543 * * *$ & 0.064 \\
\hline June & $1.026 * * *$ & 0.025 & $2.789 * * *$ & 0.070 \\
\hline July & $0.853 * * *$ & 0.025 & $2.347 * * *$ & 0.058 \\
\hline August & $0.958 * * *$ & 0.025 & $2.606 * * *$ & 0.064 \\
\hline September & $0.997 * * *$ & 0.025 & $2.710 * * *$ & 0.067 \\
\hline October & $0.525 * * *$ & 0.025 & $1.691 * * *$ & 0.042 \\
\hline November & $0.183 * * *$ & 0.025 & $1.201 * * *$ & 0.030 \\
\hline December & $0.331 * * *$ & 0.025 & $1.392 * * *$ & 0.035 \\
\hline \multicolumn{5}{|l|}{ Day of wedding } \\
\hline Tuesday & $-0.280 * * *$ & 0.019 & $0.756 * * *$ & 0.015 \\
\hline Wednesday & $-0.231 * * *$ & 0.019 & $0.793 * * *$ & 0.015 \\
\hline Thursday & -0.010 & 0.019 & 0.990 & 0.019 \\
\hline Friday & $0.998 * * *$ & 0.019 & $2.712 * * *$ & 0.052 \\
\hline Saturday & $-0.307 * * *$ & 0.019 & $0.735 * * *$ & 0.014 \\
\hline Sunday & $-2.684 * * *$ & 0.019 & $0.068 * * *$ & 0.001 \\
\hline \multicolumn{5}{|c|}{ Holidays and pre-holiday dates } \\
\hline New Year's Day & $-1.636^{* * *}$ & 0.098 & $0.195 * * *$ & 0.019 \\
\hline Carnaval Sunday & 0.160 & 0.099 & 1.173. & 0.116 \\
\hline Carnaval Monday & 0.149 & 0.099 & 1.161 & 0.114 \\
\hline Carnaval Tuesday & 0.086 & 0.099 & 1.090 & 0.107 \\
\hline Maundy Thursday & $0.364 * * *$ & 0.098 & $1.439 * * *$ & 0.141 \\
\hline
\end{tabular}




\begin{tabular}{|c|c|c|c|c|}
\hline Good Friday & $-1.510 * * *$ & 0.098 & $0.221 * * *$ & 0.022 \\
\hline Easter Sunday & $0.218 * *$ & 0.098 & $1.243 * *$ & 0.122 \\
\hline Easter Monday & $-2.138 * * *$ & 0.099 & $0.118 * * *$ & 0.012 \\
\hline Day before Queen's day & $0.522 * * *$ & 0.098 & $1.686 * * *$ & 0.165 \\
\hline Queen's Day & $-1.369 * * *$ & 0.098 & $0.254 * * *$ & 0.025 \\
\hline Liberation Day & $-1.167 * * *$ & 0.098 & $0.311 * * *$ & 0.031 \\
\hline Day before Ascen. Day & $1.277 * * *$ & 0.102 & $3.586 * * *$ & 0.365 \\
\hline Ascension Day & $-2.351 * * *$ & 0.102 & $0.095 * * *$ & 0.010 \\
\hline Whit Sunday & $-0.194 * *$ & 0.098 & $0.824 * *$ & 0.081 \\
\hline Whit Monday & $-2.616 * * *$ & 0.098 & $0.073 * * *$ & 0.007 \\
\hline $1^{\text {st }}$ day of Christmas & $-1.141 * * *$ & 0.101 & $0.320 * * *$ & 0.032 \\
\hline $2^{\text {nd }}$ day of Christmas & $-1.247 * * *$ & 0.098 & $0.287 * * *$ & 0.028 \\
\hline New Year's Eve & -0.159 & 0.098 & 0.853 & 0.084 \\
\hline Constant & $4.785 * * *$ & 0.029 & $119.7 * * *$ & 3.437 \\
\hline Observations & \multicolumn{4}{|c|}{5475} \\
\hline R-squared & \multicolumn{4}{|c|}{0.904} \\
\hline
\end{tabular}

Note: Authors' estimates from OLS regressions of the log number of daily marriages in the Netherlands on the listed temporal characteristics, using information for 5475 days from 1999-2013. Within this interval, there were 4 days with no recorded weddings. Due to the log-transformation of the dependent variable, we exclude these days from the sample.

*Significant at 0.10 level **Significant at 0.05 level $* * *$ Significant at 0.01 level 
Table 2: Average characteristics of couples married on special and ordinary days

\begin{tabular}{|c|c|c|c|c|c|}
\hline Characteristic & $\begin{array}{c}\text { Ordinary } \\
\text { date }\end{array}$ & $\begin{array}{c}\text { Valentine's } \\
\text { Day }\end{array}$ & $\begin{array}{c}\text { Same- } \\
\text { number } \\
\text { date }\end{array}$ & $\begin{array}{c}\text { Sequence } \\
\text { date }\end{array}$ & Mirror date \\
\hline
\end{tabular}

\section{Husbands}

Age at wedding

1st generation immigrant

2nd generation immigrant

Number of marriages

Education levels

- unknown

- pre-school

- primary school

- secondary school phase 1

- secondary school phase 2

- higher education, bachelors

- higher education, masters

- higher education, $\mathrm{PhD}$

Not employed

Part-time employment

Full-time employment

Months employed

Annual earnings, conditional

on employment, in $€ 1000$

\begin{tabular}{|c|c|c|c|c|}
\hline 33.96 & $34.53 * * *$ & $36.20 * * *$ & $35.29 * * *$ & $35.11 * * *$ \\
\hline 0.17 & 0.17 & $0.09 * * *$ & $0.09 * * *$ & $0.08 * * *$ \\
\hline 0.08 & $0.09 * * *$ & $0.09 * * *$ & $0.08^{*}$ & $0.07^{*}$ \\
\hline 1.19 & $1.26 * * *$ & $1.28 * * *$ & $1.23 * * *$ & $1.23 * * *$ \\
\hline 0.47 & $0.52 * * *$ & $0.49 * * *$ & $0.42 * * *$ & $0.48 *$ \\
\hline 0.01 & 0.01 & $0.01 * *$ & 0.01 & $0.01 * * *$ \\
\hline 0.02 & $0.02 *$ & 0.02 & 0.02 & $0.01 * * *$ \\
\hline 0.06 & $0.09 * * *$ & $0.08 * * *$ & $0.07 * * *$ & 0.06 \\
\hline 0.22 & 0.22 & $0.25 * * *$ & $0.27 * * *$ & $0.24 * * *$ \\
\hline 0.14 & $0.09 * * *$ & $0.11 * * *$ & 0.15 & $0.15^{* *}$ \\
\hline 0.08 & $0.04 * * *$ & $0.04 * * *$ & $0.06^{* * *}$ & $0.05^{* * *}$ \\
\hline 0.01 & $0.00 * * *$ & $0.01 * * *$ & $0.00 * *$ & $0.01 * *$ \\
\hline 0.18 & $0.20 * * *$ & $0.17 * * *$ & $0.16 * * *$ & $0.13 * * *$ \\
\hline 0.07 & 0.07 & $0.06 * * *$ & 0.06 & $0.06^{* *}$ \\
\hline 0.75 & $0.73 * * *$ & $0.77 * * *$ & $0.78 * * *$ & $0.81 * * *$ \\
\hline 9.33 & $8.96 * * *$ & $9.55 * * *$ & $9.68 * * *$ & $10.15^{* * *}$ \\
\hline 34.63 & $32.75 * * *$ & $35.49 * * *$ & $35.61 * *$ & $35.19^{*}$ \\
\hline
\end{tabular}

Wives

Age at wedding

1st generation immigrant

2nd generation immigrant

Number of marriages

Education levels

- unknown

- pre-school

- primary school

- secondary school phase 1

- secondary school phase 2

- higher education, bachelors

- higher education, masters

- higher education, $\mathrm{PhD}$

Not employed

Part-time employment

Full-time employment

Months employed

31.02

$31.72 * * *$

$33.26 * * *$

$32.36^{* * *}$

$32.13 * * *$

0.21

$0.14 * * *$

$0.12 * * *$

$0.11 * * *$

0.08

$0.10 * * *$

$0.09 *$

0.08

0.08

1.17

$1.27 * * *$

$1.26 * * *$

$1.21 * * *$

$1.21 * * *$

0.41

$0.45^{* * *}$

0.41

$0.32 * * *$

0.40

0.01

0.01

0.02

$0.03 * *$

$0.01 * * *$

0.01

$0.01 * * *$

0.06

$0.09 * * *$

$0.02 *$

$0.02 * * *$

$0.01 * * *$

0.24

$0.26 * * *$

$0.09 * * *$

$0.09 * * *$

0.07

0.16

$0.10 * * *$

$0.29 * * *$

$0.33 * * *$

$0.27 * * *$

0.08

$0.05 * * *$

$0.12 * * *$

$0.18 *$

$0.17 *$

0.01

$0.01 * * *$

$0.05 * * *$

$0.06 * * *$

$0.06 * * *$

0.23

$0.28 * * *$

$0.01 * * *$

0.01

$0.01 * * *$

0.28

$0.19 * * *$

$0.18 * * *$

$0.16^{* * *}$

0.49

$0.33 * * *$

$0.32 * * *$

$0.34 * * *$

$0.31 * * *$

8.58

$0.40 * * *$

0.49

0.48

$0.53 * * *$

$7.76 * * *$

$9.03 * * *$

$9.22 * * *$

$9.59 * * *$

22.47

$19.56 * * *$

$21.89 * * *$

22.44

$22.77 *$ on employment, in $€ 1000$ 


\section{Couple characteristics}

Mahalanobis distance measure

Premarital children in h'hold

1.58

$1.74 * * *$

$1.70 * * *$

$1.64 * * *$

1.59

Birth $<9$ months after wedding

0.28

$0.37 * * *$

$0.41 * * *$

$0.37 * * *$

$0.33 * * *$

Cohabiting before marriage

- no cohabitation

$0.15 \quad 0.22 * * *$

$0.09 * * *$

$0.11 * * *$

$0.11 * * *$

- cohabiting less than 1 year

$0.24 \quad 0.23$

$0.13 * * *$

$0.13 * * *$

$0.13 * * *$

$0.15 \quad 0.21 * * *$

$0.14 * * *$

0.15

$0.14 * * *$

- cohabiting 1-2 years

$0.13 \quad 0.13$

$0.15^{* * *}$

$0.16^{* * * *}$

$0.16^{* * *}$

- cohabiting more than 2 years

$0.48 \quad 0.42 * * *$

$0.58 * * *$

$0.56 * * *$

$0.57 * * *$

Urbanization index (1=highest, 5=lowest)

$2.67 \quad 2.70$

$2.82 * * * \quad 2.64$

$2.76^{* * *}$

Religiousness (imputed)

$0.35 \quad 0.34 * * *$

$0.33 * * *$

$0.34 * * *$

$0.34 * * *$

Social support (imputed)

0.59

$0.58 * * *$

$0.58 * * *$

0.59

$0.58 * * *$

Number of observations

$1,092,333$

4,349

14,879

4,249

8.897

Note: Authors' estimates of average characteristics from marriages of different-sex couples ages 18-60 in the Netherlands from 1999-2013.

*Different from ordinary days at 0.10 level

**Different from ordinary days at 0.05 level

$* * *$ Different from ordinary days at 0.01 level 
Table 3: Kaplan-Meier marriage failure (divorce) rates at selected durations for couples married on special and ordinary dates

\begin{tabular}{|c|c|c|c|c|c|}
\hline Duration & $\begin{array}{l}\text { Ordinary } \\
\text { date }\end{array}$ & $\begin{array}{l}\text { Valentine's } \\
\text { Day }\end{array}$ & $\begin{array}{c}\text { Same-number } \\
\text { date }\end{array}$ & $\begin{array}{c}\text { Sequence } \\
\text { date }\end{array}$ & $\begin{array}{c}\text { Mirror } \\
\text { date }\end{array}$ \\
\hline 1 year & $\begin{array}{c}0.45 \% \\
(0.44,0.46)\end{array}$ & $\begin{array}{c}1.02 \% \\
(0.76,1.37)\end{array}$ & $\begin{array}{c}0.58 \% \\
(0.47,0.72)\end{array}$ & $\begin{array}{c}0.49 \% \\
(0.31,0.78)\end{array}$ & $\begin{array}{c}0.52 \% \\
(0.39,0.69)\end{array}$ \\
\hline 3 years & $\begin{array}{c}3.82 \% \\
(3.78,3.86)\end{array}$ & $\begin{array}{c}5.54 \% \\
(4.86,6.32)\end{array}$ & $\begin{array}{c}4.98 \% \\
(4.61,5.38)\end{array}$ & $\begin{array}{c}4.34 \% \\
(3.70,5.10)\end{array}$ & $\begin{array}{c}4.18 \% \\
(3.76,4.64)\end{array}$ \\
\hline 5 years & $\begin{array}{c}7.92 \% \\
(7.87,7.98)\end{array}$ & $\begin{array}{c}11.19 \% \\
(10.16,12.32)\end{array}$ & $\begin{array}{c}10.13 \% \\
(9.58,10.72)\end{array}$ & $\begin{array}{c}8.52 \% \\
(7.52,9.65)\end{array}$ & $\begin{array}{c}8.53 \% \\
(7.91,9.19)\end{array}$ \\
\hline 7 years & $\begin{array}{c}11.96 \% \\
(11.88,12.03)\end{array}$ & $\begin{array}{c}16.89 \% \\
(15.56,18.33)\end{array}$ & $\begin{array}{c}14.82 \% \\
(14.10,15.59)\end{array}$ & $\begin{array}{c}12.95 \% \\
(11.57,14.51)\end{array}$ & $\begin{array}{c}12.53 \% \\
(11.75,13.36)\end{array}$ \\
\hline 9 years & $\begin{array}{c}15.73 \% \\
(15.65,15.82)\end{array}$ & $\begin{array}{c}21.43 \% \\
(19.86,23.12)\end{array}$ & $\begin{array}{c}19.37 \% \\
(18.47,20.31)\end{array}$ & $\begin{array}{c}17.14 \% \\
(15.37,19.11)\end{array}$ & $\begin{array}{c}16.32 \% \\
(15.37,17.33)\end{array}$ \\
\hline 11 years & $\begin{array}{c}19.30 \% \\
(19.20,19.41)\end{array}$ & $\begin{array}{c}26.32 \% \\
(24.48,28.29)\end{array}$ & $\begin{array}{c}23.73 \% \\
(22.67,24.85)\end{array}$ & $\begin{array}{c}20.99 \% \\
(18.86,23.38)\end{array}$ & $\begin{array}{c}20.15 \% \\
(19.01,21.36)\end{array}$ \\
\hline
\end{tabular}

Note: Authors' estimates of Kaplan-Meier failure rates using linked marriage, divorce, and other registry data for marriages of different-sex couples ages 18-60 in the Netherlands from 1999-2013. 95\% confidence intervals appear in parentheses. 
Table 4: Exponentiated coefficient estimates from Cox PH models of marriage duration

\begin{tabular}{|c|c|c|c|c|c|c|}
\hline \multirow[t]{2}{*}{ Variables } & \multicolumn{2}{|c|}{ Baseline } & \multicolumn{2}{|c|}{ Temporal covariates } & \multicolumn{2}{|c|}{ Full specification } \\
\hline & Coefficient & s.e. & Coefficient & s.e. & Coefficient & s.e. \\
\hline \multicolumn{7}{|l|}{ Special dates } \\
\hline Valentine's Day & $1.381 * * *$ & 0.049 & $1.268 * * *$ & 0.048 & $1.114 * * *$ & 0.042 \\
\hline Same number date & $1.258 * * *$ & 0.028 & $1.300 * * *$ & 0.030 & $1.172 * * *$ & 0.027 \\
\hline Sequence date & $1.154 * * *$ & 0.063 & $1.186 * * *$ & 0.065 & $1.097 *$ & 0.061 \\
\hline Mirror date & 1.026 & 0.030 & 1.034 & 0.031 & 1.034 & 0.031 \\
\hline \multicolumn{7}{|l|}{ Year of wedding } \\
\hline 2000 & & & 0.987 & 0.010 & 0.995 & 0.010 \\
\hline 2001 & & & $0.968 * * *$ & 0.010 & $0.980 * *$ & 0.010 \\
\hline 2002 & & & $0.974 * *$ & 0.010 & 0.989 & 0.011 \\
\hline 2003 & & & $0.938 * * *$ & 0.010 & $0.968 * * *$ & 0.011 \\
\hline 2004 & & & $0.888 * * *$ & 0.010 & $0.930 * * *$ & 0.011 \\
\hline 2005 & & & $0.869 * * *$ & 0.011 & $0.899 * * *$ & 0.012 \\
\hline 2006 & & & $0.840 * * *$ & 0.011 & $0.883 * * *$ & 0.012 \\
\hline 2007 & & & $0.832 * * *$ & 0.012 & $0.869 * * *$ & 0.013 \\
\hline 2008 & & & $0.854 * * *$ & 0.012 & $0.897 * * *$ & 0.014 \\
\hline 2009 & & & $0.855 * * *$ & 0.014 & $0.901 * * *$ & 0.015 \\
\hline 2010 & & & $0.845^{* * *}$ & 0.016 & $0.886 * * *$ & 0.017 \\
\hline 2011 & & & $0.839 * * *$ & 0.021 & $0.882 * * *$ & 0.022 \\
\hline 2012 & & & $0.851 * * *$ & 0.033 & $0.886 * * *$ & 0.034 \\
\hline 2013 & & & $0.725^{* *}$ & 0.096 & $0.725^{* *}$ & 0.097 \\
\hline \multicolumn{7}{|l|}{ Month of wedding } \\
\hline February & & & $0.918 * * *$ & 0.016 & $0.943 * * *$ & 0.017 \\
\hline March & & & $0.938 * * *$ & 0.016 & $0.973^{*}$ & 0.016 \\
\hline April & & & $0.837 * * *$ & 0.014 & $0.901 * * *$ & 0.015 \\
\hline May & & & $0.856^{* * *}$ & 0.013 & $0.921 * * *$ & 0.014 \\
\hline June & & & $0.887 * * *$ & 0.013 & $0.939 * * *$ & 0.014 \\
\hline July & & & $0.968 * *$ & 0.014 & $0.943 * * *$ & 0.014 \\
\hline August & & & $0.960 * * *$ & 0.014 & $0.945 * * *$ & 0.014 \\
\hline September & & & $0.858 * * *$ & 0.013 & $0.916 * * *$ & 0.014 \\
\hline October & & & $0.849 * * *$ & 0.014 & $0.900 * * *$ & 0.015 \\
\hline November & & & $0.931 * * *$ & 0.016 & $0.953 * * *$ & 0.016 \\
\hline December & & & $0.948 * * *$ & 0.016 & 0.976 & 0.016 \\
\hline \multicolumn{7}{|l|}{ Day of wedding } \\
\hline Tuesday & & & $0.960 * * *$ & 0.010 & $0.965 * * *$ & 0.010 \\
\hline Wednesday & & & $0.886 * * *$ & 0.009 & $0.940 * * *$ & 0.010 \\
\hline Thursday & & & $0.735 * * *$ & 0.007 & $0.858 * * *$ & 0.009 \\
\hline Friday & & & $0.692 * * *$ & 0.006 & $0.849 * * *$ & 0.007 \\
\hline Saturday & & & $0.523 * * *$ & 0.006 & $0.817 * * *$ & 0.010 \\
\hline Sunday & & & $0.478 * * *$ & 0.016 & $0.705 * * *$ & 0.025 \\
\hline \multicolumn{7}{|c|}{ Traditional and public holidays } \\
\hline New Year's Day & & & 0.854 & 0.123 & $1.373 * *$ & 0.208 \\
\hline Carnival Sunday & & & 1.228 & 0.260 & 1.274 & 0.282 \\
\hline Carnival Monday & & & $1.133^{* *}$ & 0.071 & 1.095 & 0.069 \\
\hline Carnival Tuesday & & & 0.997 & 0.060 & 0.987 & 0.056 \\
\hline Maundy Thursday & & & $1.086^{*}$ & 0.048 & 1.071 & 0.048 \\
\hline Good Friday & & & 1.090 & 0.087 & 0.990 & 0.080 \\
\hline
\end{tabular}


Easter Sunday
Easter Monday
Day before Queen's day
Queen's Day
Liberation Day
Day before Ascen. Day
Ascension Day
Whit Sunday
Whit Monday
Christmas Day
2nd day of Christmas
New Year's Eve

Husband's characteristics

1 st gen. immigrant, husb.

2nd gen. immigrant, husb.

Husb. married for $2^{\text {nd }}$ time

Husb. married for $3^{\text {rd }}$ time

Husb. married for $4^{\text {th }}+$ time

Education levels, husband

pre-school

primary school

secondary school phase 1

secondary school phase 2

higher education, bachelors

higher education, masters

higher education, $\mathrm{PhD}$

Husband's employment

Not employed

Part-time employed

Worked 1 month

Worked 2 months

Worked 3 months

Worked 4 months

Worked 5 months

Worked 6 months

Worked 7 months

Worked 8 months

Worked 9 months

Worked 10 months

Worked 11 months

Spline of husband's log earnings

Slope 0-25th quantile

Slope 25-50th quantile

Slope 50-75th quantile

Slope 75-100th quantile

Husband's industry (only $2^{\text {nd }}-4^{\text {th }}$ largest reported)

Business services (6.8\%)

Lending companies (5.2\%)

Healthcare $(3.9 \%)$

$\begin{array}{llll}1.043 & 0.230 & 1.244 & 0.348 \\ 0.733^{* *} & 0.115 & 0.878 & 0.143 \\ 0.794^{* * *} & 0.038 & 0.895^{* *} & 0.043 \\ 0.935 & 0.115 & 1.143 & 0.146 \\ 0.971 & 0.082 & 1.044 & 0.093 \\ 0.705^{* * *} & 0.021 & 0.841^{* * *} & 0.026 \\ 1.114 & 0.160 & 1.243 & 0.184 \\ 0.942 & 0.230 & 1.097 & 0.296 \\ 0.927 & 0.135 & 1.165 & 0.180 \\ 0.745^{* *} & 0.101 & 0.832 & 0.121 \\ 0.887 & 0.110 & 1.014 & 0.129 \\ 1.226^{* * *} & 0.074 & 1.115^{*} & 0.068\end{array}$

$0.990 \quad 0.009$

$0.959 * * * \quad 0.010$

$1.181 * * * \quad 0.010$

$1.408 * * * \quad 0.025$

$1.357 * * * \quad 0.056$

$0.862 * * * \quad 0.020$

$1.040 * * * \quad 0.016$

$1.136 * * * \quad 0.011$

$1.000 \quad 0.007$

$0.688 * * * \quad 0.007$

$0.593 * * * \quad 0.009$

$0.486^{* * *} \quad 0.021$

$1.092 * * \quad 0.044$

$1.002 \quad 0.013$

$1.073 * \quad 0.045$

$1.099 * * * \quad 0.037$

$1.136 * * * \quad 0.040$

$1.127 * * * \quad 0.034$

$1.143 * * * \quad 0.037$

$1.117 * * * \quad 0.033$

$1.109 * * * \quad 0.031$

$1.119 * * * \quad 0.030$

$1.170 * * * \quad 0.028$

$1.123 * * * \quad 0.025$

$1.167 * * * \quad 0.022$

$0.954 * * * \quad 0.012$

$0.544 * * * \quad 0.025$

$0.920 * \quad 0.046$

$0.870 * * * \quad 0.020$

$1.111^{* * *} \quad 0.020$

$1.411 * * * \quad 0.021$

$1.193 * * * \quad 0.022$ 


\section{Wife's characteristics}

1 st gen. immigrant, wife

$0.836 * * * \quad 0.008$

2nd gen. immigrant, wife

$0.954 * * * \quad 0.009$

Wife married for $2^{\text {nd }}$ time

$1.244 * * * \quad 0.011$

Wife married for $3^{\text {rd }}$ time

$1.624 * * * \quad 0.029$

Wife married for $4^{\text {th }}+$ time

$1.810 * * * \quad 0.069$

Education levels, wife

pre-school

$0.958 * * \quad 0.020$

primary school

$1.358 * * * \quad 0.019$

secondary school phase 1

$1.547 * * * \quad 0.015$

secondary school phase 2

$1.392 * * * \quad 0.010$

higher education, bachelors

$0.992 \quad 0.010$

higher education, masters

$0.882 * * * \quad 0.013$

higher education, $\mathrm{PhD}$

$0.638 * * * \quad 0.027$

Wife's employment

Not employed

Part-time employed

0.978

0.028

Worked 1 month

$0.925 * * * \quad 0.007$

Worked 2 months

$1.080 * * \quad 0.033$

Worked 3 months

$1.078 * * * \quad 0.028$

Worked 4 months

$1.064 * * \quad 0.030$

Worked 5 months

$1.111 * * * \quad 0.027$

$1.051 * \quad 0.028$

Worked 6 months

$1.060 * * \quad 0.026$

Worked 7 months

$1.138 * * * \quad 0.027$

Worked 8 months

$1.167 * * * \quad 0.026$

Worked 9 months

Worked 10 months

$1.140 * * * \quad 0.024$

$1.098 * * * \quad 0.022$

Worked 11 months

$1.149 * * * \quad 0.020$

Spline of wife's log earnings

Slope 0-25th quantile

Slope 25-50th quantile

$0.930 * * * \quad 0.010$

$0.793 * * * \quad 0.023$

Slope 50-75th quantile

Slope 75-100th quantile

Wife's industry (only $2^{\text {nd }}-4^{\text {th }}$ largest reported)

$1.023 \quad 0.045$

$1.003 \quad 0.031$

Public jobs - education \& science $(6.3 \%)$

$0.928 * * * \quad 0.015$

Retail (5.4\%)

Lending companies (5.4\%)

$1.080 * * * \quad 0.014$

$1.364 * * * \quad 0.017$

Couple characteristics

Spline of Mahalanobis distance

Slope 0-25th quantile

$1.271 * * * \quad 0.036$

Slope 25-50th quantile

$1.223 * * * \quad 0.020$

Slope 50-75th quantile

$1.127 * * * \quad 0.013$

Slope 75-100th quantile

$1.221 * * * \quad 0.007$

Cohabiting less than 1 year

$1.325 * * * \quad 0.012$

Cohabiting 1-2 years

$1.185 * * * \quad 0.012$

Cohab. more than 2 years

Premarital children in $\mathrm{HH}$

Birth $<9$ months after wed.

$1.167 * * * \quad 0.010$

$1.349 * * * \quad 0.009$

Urbanisation of municipality

High urbanisation

$0.922 * * * \quad 0.007$

$1.001 \quad 0.008$ 


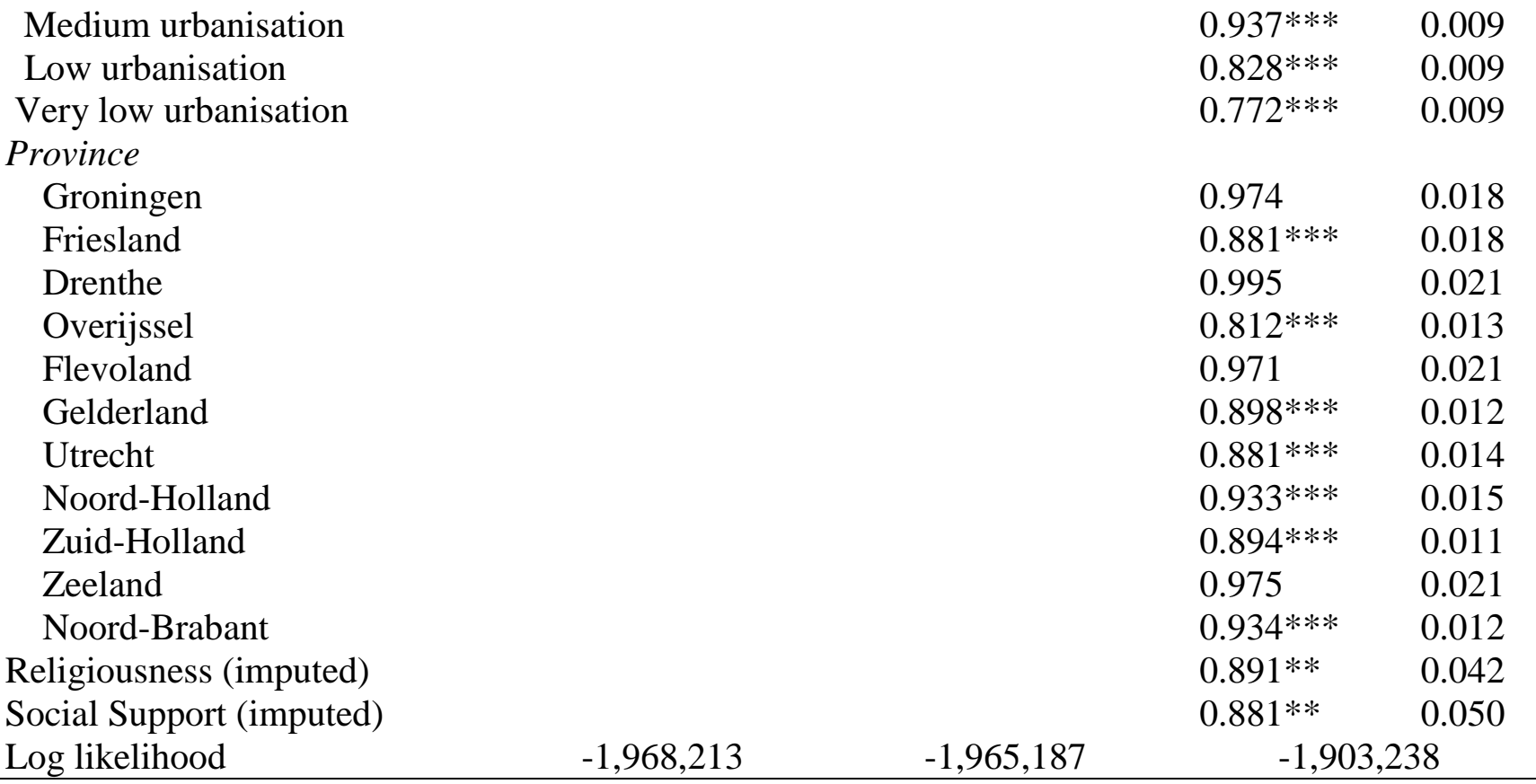

Note: Authors' estimates from Cox PH models of marriage durations using linked marriage, divorce, and other registry data for 1,146,783 marriages of different-sex couples ages 18-60 in the Netherlands from 1999-2013. The specification in the third column also includes dummy controls for the husbands' and wives' ages, which are graphed in Figure 3, and controls for 69 industrial sectors.

*Significant at 0.10 level

**Significant at 0.05 level

$* * *$ Significant at 0.01 level 
Table 5: Exponentiated coefficient estimates from Cox PH models of marriage duration, models with reduced sets of covariates and alternative samples

\begin{tabular}{|c|c|c|c|c|c|c|c|c|}
\hline \multirow[t]{2}{*}{ Specification } & \multicolumn{2}{|c|}{ Valentine's Day } & \multicolumn{2}{|c|}{ Same number date } & \multicolumn{2}{|c|}{ Sequence date } & \multicolumn{2}{|c|}{ Mirror date } \\
\hline & Coefficient & s.e. & Coefficient & s.e. & Coefficient & s.e. & Coefficient & s.e. \\
\hline 1 - Excluding employment & $1.119 * * *$ & 0.043 & $1.189 * * *$ & 0.028 & $1.103^{*}$ & 0.061 & 1.028 & 0.031 \\
\hline 2 - Excluding geography & $1.117 * * *$ & 0.043 & $1.165^{* * *}$ & 0.027 & $1.098^{*}$ & 0.061 & 1.023 & 0.031 \\
\hline 3 - Excluding family characteristics & $1.146 * * *$ & 0.044 & $1.194 * * *$ & 0.028 & $1.104 *$ & 0.061 & 1.040 & 0.031 \\
\hline 4 - Excluding Mahalanobis distance & $1.129 * * *$ & 0.043 & $1.183 * * *$ & 0.028 & $1.114 * *$ & 0.062 & 1.045 & 0.031 \\
\hline 5 - Excluding education levels & $1.142 * * *$ & 0.044 & $1.210 * * *$ & 0.028 & $1.123 * *$ & 0.062 & 1.045 & 0.031 \\
\hline 6 - Excluding age dummies & $1.143 * * *$ & 0.044 & $1.177 * * *$ & 0.027 & $1.112 *$ & 0.062 & 1.044 & 0.031 \\
\hline 7 - Excl. spouses with missing education levels & $1.145^{* *}$ & 0.077 & $1.245 * * *$ & 0.049 & $1.155^{*}$ & 0.099 & $1.094 *$ & 0.056 \\
\hline 8 - Extending the sample to $1995-2013$ & $1.139 * * *$ & 0.035 & $1.180 * * *$ & 0.027 & $1.104^{*}$ & 0.061 & 1.037 & 0.031 \\
\hline 9 - Same specification as 8 in $1999-2013$ & $1.119 * * *$ & 0.043 & $1.189 * * *$ & 0.027 & $1.103^{*}$ & 0.061 & 1.028 & 0.031 \\
\hline $\begin{array}{l}10-\text { Province/birth-year interactions in place of } \\
\text { imputed measures }\end{array}$ & $1.115 * * *$ & 0.043 & $1.170 * * *$ & 0.027 & $1.098^{*}$ & 0.061 & 1.033 & 0.031 \\
\hline 11 - Adding month-weekday interaction terms & $1.114 * * *$ & 0.043 & $1.157 * * *$ & 0.028 & 1.059 & 0.060 & 1.033 & 0.031 \\
\hline 12 - Sample restricted to first marriages & $1.169 * * *$ & 0.057 & $1.196 * * *$ & 0.034 & 1.112 & 0.074 & 1.060 & 0.039 \\
\hline 13 - Sample restricted to remarriages & 1.030 & 0.063 & $1.126 * * *$ & 0.045 & 1.052 & 0.106 & 0.995 & 0.051 \\
\hline 14 - Sample rest. to non-cohabiting couples & $1.149 *$ & 0.091 & $1.158 * *$ & 0.079 & 0.962 & 0.149 & 1.022 & 0.084 \\
\hline 15 - Sample restricted to cohabiting couples & $1.091 * *$ & 0.048 & $1.152 * * *$ & 0.029 & 1.096 & 0.065 & 1.032 & 0.033 \\
\hline
\end{tabular}

Note: Authors' estimates from Cox PH models of marriage durations using linked marriage, divorce, and other registry data for marriages of different-sex couples ages 18-60 in the Netherlands from 1999-2013. Apart from the variables specified in the table, each specification includes the full set of covariates of the model in the third column of Table 3. The specifications 8 and 9 do not contain the employment and geographic characteristics, as these were not available prior to 1999.

*Significant at 0.10 level

**Significant at 0.05 level

*** Significant at 0.01 level 


\section{University Library}

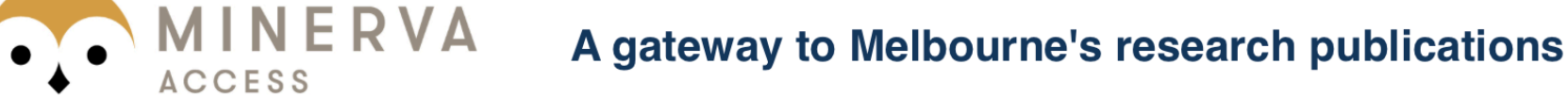

Minerva Access is the Institutional Repository of The University of Melbourne

Author/s:

Kabatek, J;Ribar, DC

Title:

Not your lucky day: romantically and numerically special wedding date divorce risks

Date:

2018-10-01

Citation:

Kabatek, J. \& Ribar, D. C. (2018). Not your lucky day: romantically and numerically special wedding date divorce risks. JOURNAL OF POPULATION ECONOMICS, 31 (4), pp.1067-1095. https://doi.org/10.1007/s00148-017-0684-6.

Persistent Link:

http://hdl.handle.net/11343/282857 